\title{
Festa e sociabilidade: reflexões teóricas e práticas para a pesquisa dos festejos como fenômenos urbanos contemporâneos
}

\author{
Guilherme Guimarães Leonel*
}

\begin{abstract}
Resumo
As festas e as religiosidades populares são, há muito tempo, temas recorrentes na pesquisa de folcloristas, memorialistas e pesquisadores acadêmicos. Porém, nem sempre tais fenômenos foram/são devidamente dimensionados e problematizados, levando-se em conta sua efetiva relevância e complexidade social, tanto no passado como no presente. $\mathrm{O}$ objetivo deste artigo é elencar e propor novos olhares e perspectivas de pesquisa social em relação às festas, às religiosidades e a outras manifestações populares, problematizando-os e lançando nova luz sobre tais fenômenos. É possível promover recortes transversais e interdisciplinares de análise que possam resultar em abordagens diferenciadas do fenômeno festivo em suas continuidades e singularidades.
\end{abstract}

Palavras-chave: Festa; Sociabilidade; Cultura popular.

As considerações traçadas nesse artigo visam delinear reflexões teóricas que possam, de alguma forma, contribuir para que os estudos das festas e das religiosidades populares sejam empreendidos a partir de novas perspectivas analíticas e, de preferência, sejam estruturado através de perspectivas interdisciplinares, conjugando-se conhecimentos da história, da sociologia, da antropologia etc.

Segundo a sociologia simmeliana, festa é uma "forma" capaz de plasmar conteúdos diversos, e destinada à promoção de laços de sociabilidade, mesmo que conflitantes. Assim compreendida a festa, tento em seguida estabelecer as conexões possíveis entre tal concepção do fenômeno e questões como urbanidade, diversidade, memória, identidades e conflitos. Ao fim, tento demonstrar brevemente, através da análise diacrônica e sincrônica das festas do Reinado/Congado em Divinópolis/MG, promovidas por minha pesquisa, como é possível aplicar tais referenciais teóricos no intuito de captar a complexidade das manifestações festivas como fenômenos sociais.

\footnotetext{
${ }^{*}$ Mestre em Ciências Sociais pela Pontifícia Universidade Católica (PUC Minas). Professor de Sociologia do Instituto Federal de Minas Gerais (IFMG).
} 


\section{A festa como forma de sociação e sociabilidade}

Ora sendo vistas como mero divertimento, ora como excentricidades da vida social, ou mesmo como sobrevivência de certos arcaísmos tradicionais, as festas, com sua desordem, confusão, indefinição de fronteiras, sempre trouxeram aos estudiosos da sociedade e da cultura certo atordoamento, por não saberem eles como tratá-las e abordá-las. Por isso mesmo as festas permaneceram, por muito tempo, quase que exclusivamente como objeto de estudo de folcloristas e memorialistas. No entanto, pode-se dizer que vem ocorrendo uma grande multiplicação de trabalhos científicos que tomam tais fenômenos como objeto de estudo. Concomitante à tomada das festas como objeto de estudo pelas ciências sociais, ocorreu um quadro de mudança substancial nas suas formas de abordagem: sua análise se politizou, colocando-se tais manifestações como formas fundamentais de sociabilidade e palco do desenrolar de conflitos e de tensões sociais.

Nessa perspectiva, é possível extrapolar suas formas manifestas considerando-as como formas de sociação, como no conceito simmeliano, ou seja, formas específicas de ser com/e para com o outro. Assim, vínculos sociais seriam gerados na celebração e na estetização da vida, promovidas pelas festas. Segundo Perez, se utilizarmos o pensamento de Simmel como pedra fundamental, é possível pensar, através do fenômeno festivo, os fundamentos dos vínculos coletivos que tecem a sociedade. Assim, a festa como forma de sociação, teria seu acento no estar-junto e no relacionarse:

\footnotetext{
A forma lúdica de sociação não tem conteúdo, nem propósitos objetivos, nem resultados exteriores, é uma estrutura sociológica que, em sua relação com a sociação concreta, determinada pelo conteúdo, é semelhante à relação do trabalho de arte com a realidade. (PEREZ, 2002, p.19)
}

Na perspectiva de Simmel, a sociabilidade é "o jogo no qual se faz de conta que são todos iguais, ao mesmo tempo que cada um é reverenciado em particular", e segundo suas próprias palavras, "fazer de conta não é mentira" (SIMMEL, 2006, p.173). Essa conexão estabelecida por Simmel entre jogo e sociabilidade, pauta-se na ideia de que quase todas as formas de interação e de sociação podem ser consideradas formas sociais lúdicas. Por isso, em Simmel, a expressão jogo social é uma das características mais fundamentais das interações e das sociações entre homens: o jogo não é só praticado em sociedade como as pessoas realmente "jogam sociedade" (SIMMEL, 
2006, p.174). O jogo, a arte, a religião ou as festas, nessa perspectiva, são mais que um simples faz de conta, são uma forma de estar-junto - nem sempre em harmonia. Assim, compõem uma série de meios diversos de se experienciar a vida em coletividade, ou seja, uma forma lúdica de sociação.

Segundo Perez (2002), a singularidade das festas, como fenômeno social, estaria na sua condição de ato coletivo extralógico, extratemporal e extraordinário, consagrando a reunião através da libertação da temporalidade linear. A lógica da utilidade e do cálculo são aí substituídos pela lógica do excesso, pelo lúdico e pela exaltação dos sentidos, com forte acento hedonístico e agonístico. Mesmo assim, é importante que se distinga a festa tanto do ritual quanto da mera diversão. Obviamente, a festa possui aspectos rituais e de divertimento. Porém, seus aspectos rituais e recreativos ganharam, com base em Durkheim, função expressiva e estética de representação de dimensões mais elementares da vida em sociedade. Tais ritos foram interpretados por Durkheim como representações dramático-coletivas da partilha do sentimento comum de sociação. No cumprimento desse papel elementar ser-lhes-iam estranhos quaisquer fins utilitários.

Tal noção é habilmente costurada à noção de sociabilidade de Simmel, através da abordagem de Perez. Sua proposta de uma "antropologia das efervescências coletivas" parte da concepção durkheimiana das festas como agrupamentos massivos geradores de exaltação e efervescência coletivas, nas quais a influência corroborativa da sociedade se faz sentir em maior evidência, pois a interações sociais tornam-se mais evidentes e ativas (PEREZ, 2002, p.22). Na referida autora encontro a confluência teórica de dois autores fundamentais da sociologia clássica, Durkheim e Simmel, quanto à compreensão dos fenômenos festivos e religiosos como práticas e representações culturais. A análise desses fenômenos não deve ficar apenas na superfície manifesta, ou seja, nos conteúdos, mas deve-se também compreendê-los mais a fundo, como formas geradoras de relações de sociabilidade, aproximando-os das formas puras sociológicas nos quais, relacionar-se é a questão mais fundamental.

Por cumprirem importante função social, e por sua generalidade, tais formas sociológicas podem plasmar conteúdos diversos, principalmente em um mundo composto pelo conflito e pela diversidade. São as relações sociais específicas de cada contexto histórico e suas singularidades que garantem a multiplicidade das manifestações dessa forma de sociação, garantindo-lhes os significados mais diversos. Esses aspectos confluentes da análise simmeliana e da durkheiminana têm influenciado, 
contemporaneamente, diversas abordagens dos fenômenos festivos, inclusive aqueles que transitam interdisciplinarmente entre as linhas limítrofes da antropologia, sociologia e da história. A análise de Perez faz dela uma importante pesquisadora brasileira cujo pensamento encontra-se articulado, teoricamente, de maneira mais representativa, em sua antropologia das efervescências coletivas.

Associando tal preceito à noção simmeliana da sociabilidade como, um jogo de produção de vínculos sociais - nem sempre harmoniosos -, é possível construir um novo ângulo de análise. A festa como sociabilidade pela sociabilidade basear-se-ia não só em interesses racional-utilitários, mas em interesses emocional-afetivos. A ação festiva como rito de realiança social de Durkheim, associada à concepção simmeliana da forma lúdica nos traz a compreensão de que os vínculos sociais são produzidos dentro de um contexto de regras - nem sempre explícitas -, de hierarquizações e, até mesmo, de conflitos. Nesse ponto é fundamental que se recorde que na concepção simmeliana, também o conflito é gerador de sociação.

Toda festa, na concepção durkheimiana, é um tempo consagrado. No entanto, é preciso considerar que se o fenômeno festivo rompe com a rotina, conecta-se ao cotidiano pregresso e posterior a ele quando se espraia por diversos meios através dos períodos não-festivos. Canclini (1982) nos ensinou que a profusão de práticas integrantes da festa não se limita apenas às suas formas manifestas no período consagrado de catarse festiva, mas penetra todo o cotidiano através de práticas, preparativos e sentidos que constituem, também, a festa em si, mesmo quando não no período festivo. A festa, mesmo que não-religiosa, consagra um tempo. Assim o faz apontando tanto para sentidos "extra-mundanos" (durkheimianos) quanto "intramundanos" (weberianos). A religião e a prática festiva, ao consagrar um determinado tempo dominado pela catarse, só o faz através de práticas cotidianas. O sagrado, espraiado no cotidiano e nas práticas mundanas - como na teoria weberiana da salvação intra-mundana -, daria ao homem, mesmo que através de práticas festivas, a possibilidade da auto-salvação.

Portanto, a festa religiosa reúne em si aspectos paradoxais que lhes são estruturais: rompe com o cotidiano, mas conecta-se a ele, pois não se entra neste tempo consagrado - ou em contato propriamente com o sagrado - sem que uma série de precauções sejam tomadas. A festa é, necessariamente, desordem, no sentido de transgressão das interdições e das barreiras usuais, mas não significa, obrigatoriamente, ausência completa de ordem, pois define quase sempre protocolos a serem seguidos. A 
festa guarda em si, mesmo que laica, algo de religioso. Nesse sentido, é preciso compreender a hipótese lançada por Durkheim, tomada por Perez como pedra fundamental de sua antropologia das efervescências coletivas, de que a idéia mesma de religioso, teria nascido em meios sociais efervescentes, assim como da própria efervescência festiva.

Sobretudo hoje, a festa possui aspectos espetaculares. Como espetáculo, com sua música, teatralidade e sensualidade, ela distingue aqueles que participam ativamente, impondo ao mesmo tempo a participação, o estar-junto, caracterizado pelo abandono de si na confusão com o outro. Ambivalentemente, a festa reúne angústia e alegria, prazer e dor, regozijo e violência, sagrado e profano, ordem e desordem. Desse modo, compreende-se que a "desordem festiva, o tumulto festivo, a violência festiva são fundadores, criadores da própria humanidade" (PEREZ, 2002, p.29). Assim, a festa constitui, como sugere Simmel, uma série de formas de sociação e de sociabilidade, ou seja, de formas de "estar-junto jogando sociedade".

\section{Festas, diversidade e cidades}

No Brasil, falar de festas exige compreender a profunda multiplicidade e diversidade de suas práticas e formas de organização. Tal ressalva evita que deixemos de lado a multiplicidade estruturante da sociedade brasileira, a constante mobilidade e plasticidade na composição de suas formas sociais, que resulta numa profunda hibridização de códigos. Essa porosidade é que estruturaria o principal mecanismo de orientação social no Brasil. No multiverso brasileiro, a festa se configuraria como um importante mecanismo de operação de ligações, pouco importando se religiosa ou profana. Não se trata, no entanto, de hipostasiar sua importância alegando que tudo é festa no Brasil. Como ângulo possível de compreensão da sociedade, e entendida como forma lúdica de sociação, a festa é um fenômeno gerador de imagens multiformes da vida coletiva. Encarada como modo privilegiado de expressão dos sentimentos coletivos, o estudo da sociabilidade festiva permitiria uma forma privilegiada de compreensão da experiência humana de produção de vínculos sociais.

No contexto da formação das cidades no Brasil, é preciso avaliar historicamente que as festas religiosas foram as atividades coletivas urbanas mais antigas. Até o século $\mathrm{XIX}$, as festas foram os acontecimentos mais importantes das cidades brasileiras, fonte de lazer coletivo e de presença no espaço público. No período colonial, o 
comparecimento a alguns festejos religiosos era obrigatório, cabendo às câmaras municipais e às confrarias fiscalizar a presença dos moradores. As festas, os cortejos e as procissões reuniam um grande contingente populacional, permitindo a aglomeração e criando oportunidades para formas diferenciadas de apropriação do espaço público, distintas daquelas presentes no cotidiano das cidades, como mostraram os estudos os diversos de historiadores como Silvia Hunold Lara (2002), João José Reis (2002), Martha Abreu (1999), Carlos Eugênio Líbano Soares (2002), Patrícia Vargas Lopes de Araújo (2008), dentre outros. A culminância das festas sempre foi obrigatoriamente precedida de intensos preparativos e de captação de fundos, o que fez das irmandades importantes instituições e dos festeiros importantes atores sociais, em termos de uma economia local e regional.

A disposição do tempo nas cidades se organizou, desde o período colonial, no Brasil, em função dos "tempos de festa". Vários viajantes europeus espantaram-se com a nossa multiplicidade de dias santos, de festas e de feriados. Tais festejos, mesmo que religiosos, envolviam uma série de atividades simultâneas, capazes de engendrar uma robusta economia sazonal: barraquinhas, feiras, danças, música, peças teatrais, fogos de artifício, enfim, um grande espetáculo que modificava radicalmente a quase sempre monótona paisagem urbana, inclusive em termos populacionais. Nesse percurso histórico, mesmo dada a grande influência da ação catequizadora cristã, consagrou-se uma religiosidade pouco atenta ao sentido íntimo das cerimônias institucionais. Ao contrário, a religiosidade que daí surgiu foi marcada por sua exterioridade e pela diluição de fronteiras entre o sagrado e o profano, o público e o privado, mais orientada para o concreto e para o mundano do que para abstrações de cunho institucional.

Nessa religiosidade, o sagrado ganha familiaridade com a intimidade dos santos. A ordem religiosa confunde-se com a ordem familiar. Nela também se contrapõe o viver em comunidade ao viver hierarquizado. Por isso, seu ponto forte é a efervescência festiva coletiva, dionisíaca e carnavalesca, vivida teatralmente, coletivamente e publicamente. As procissões de festas religiosas são, de acordo com Perez, formas de espetáculo por excelência, consagradas pela nossa sociedade, e mostram "uma maneira singular de viver a sociedade e perceber o mundo e de com ele se relacionar." (2002, p.46) No Brasil, ao longo de sua história, frequentemente a festa ocupou o espaço público e o seu centro - as praças públicas e os largos de igrejas -, gerando ali uma simbolização e uma espetacularização da coisa pública e dos dramas privados. 
A cidade brasileira, como um fantástico "híbrido sociológico que funciona de maneira singular" (PEREZ, 2002, p.47), foi e é o lugar das festas, promovendo uma incessante mistura de pessoas, códigos, trocas e transações econômicas, cindindo de um lado e unindo de outro. Assim, também a festa encenada no palco da cidade brasileira promoveu o encontro com a diversidade de pessoas e com a variedade de coisas, inventando hierarquias às avessas, concomitantemente ao fornecimento do cenário para os conflitos, dissimulações, negociações e hierarquizações um tanto mais reais. Tais conflitos, socialmente subjacentes à existência das práticas festivas, fizeram dos tempos de efervescência coletiva momentos de apropriação do cenário público, de usos do espaço e de domínio, mesmo que passageiro, da rua. A festa, com seu caráter dialético transitório-rotineiro, introduziu elementos persistentes em nossa sociabilidade, perpassando e alinhavando as práticas privadas e públicas nos espaços urbanos.

\section{Festa, memória, identidades e conflito}

As festas constituem um campo fecundo para se pensar a sociedade nas suas continuidades como, também, em seus movimentos de transição, de vaivém, marcados por rupturas. A análise do fenômeno social festivo nos permite o trânsito por territórios da vida coletiva no seu nível mais elementar, ou seja, nas estruturas de formação dos próprios vínculos sociais, pois permite que a sociedade entre em uma relação consigo própria, diferente daquela ordinária, desempenhada em sua rotina. Ao romper com a rotina, a festa mostra-se capaz de, paradoxalmente, produzir o próprio cotidiano e o inédito como atos de produção do próprio vínculo social, num processo dialético de caos e ordem, produtor da própria vida em sociedade.

A experiência religiosa no Brasil, principalmente aquela marcada pelo catolicismo popular e pela cultura afro, exemplificadas no caso dos Reinados/Congados de Divinópolis/MG, é perpassada estruturalmente pela dimensão festiva, expressa de forma metafórica e performativa, e intensamente impregnada pelo cotidiano, ou seja, pelo mundo do profano. Apesar de as manifestações religiosas ganharem traços cada vez mais individuais, a religiosidade e a festas permanecem atuando na reativação da memória coletiva. A festa e a religiosidade guardam continuidades importantes para a compreensão da formação da sociedade brasileira. No entanto, sua existência, no presente impõe uma questão obrigatória: quais seriam os significados das festas e da religiosidade popular em nossa sociedade moderna e urbana? 
As manifestações culturais não estão soltas na sociedade, mas estão atreladas às relações sociais, de forma que as novas condições socioculturais abrem múltiplas perspectivas para o comportamento individual e coletivo na vida em sociedade. As profundas modificações na vida em sociedade, verificadas principalmente ao longo do último século, transformaram profundamente as relações sociais, ou seja, as formas pelas quais os indivíduos ligam-se uns aos outros. O processo de urbanização, talvez, seja o aspecto mais emblemático dessas transformações. O processo de desenraizamento cultural e de recriação cultural nas cidades, particularmente por parte das camadas mais populares, promoveu profundas transformações nas formas de organização e de concepção de mundo dos grupos sociais.

Tais práticas estão em constante movimento, e suas formas de reprodução, preservação e manifestação estão sintonizadas com as profundas mudanças. A cultura popular está permeada por múltiplos atores, lastreada de continuidade/descontinuidades, contraposta por historicidades diversas (PASSOS, 2002, p.168). A compreensão dos diversos significados das festas faz com que sua concepção não se restrinja apenas às suas formas manifestas, como nas abordagens folcloristas. De acordo com Passos, devese vê-los como um processo cultural vivenciado no seio da sociedade, através de um conjunto de práticas diversas e dispersas (PASSOS, 2002, p.169), instituindo maneiras de fazer, de atualizar e de expressar recriadas e reinventadas ao longo do tempo. A recriação e a reinvenção, presentes dentro da sociabilidade festiva são mais que simples reprodução ou inversão de sentidos. São, também, possibilidades de produção do inédito e de novas formas de se estar em sociedade.

O universo do catolicismo popular, segundo Passos (2002), teria criado um mundo povoado de mistérios e de rituais próprios, encobrindo a vida e a história das comunidades e famílias, engendrando formas diferenciadas de representação simbólica. Não se trataria, segundo o autor, de reter ou classificar o que ficou de católico, de africano, ou de lusitano, mas de compreender que, apesar de profundas continuidades e investidas institucionais, tais manifestações são capazes de recriar uma série de normas, regras, valores, expressões, gestos e práticas em contato com o presente e com as mudanças sociais.

No universo do catolicismo popular, a religiosidade frequentemente se manifesta através da devoção aos santos, das procissões e das romarias, dos cortejos e das danças, das orações e das invocações de perdões e milagres, geralmente expressos em palavras, ações e gestos coletivos. Através deles, sentimentos, laços, conflitos e valores são 
rememorados ciclicamente em determinados períodos do ano, sob a forma de práticas que dialogam, a todo tempo, com as conjunturas históricas em questão.

É importante lembrar que se hoje o catolicismo não goza mais do monopólio do mercado brasileiro de bens de salvação, durante todo o período colonial e parte do imperial ele exerceu importante função dentro dos arranjos sociais constituídos no Brasil. Esta influência possui uma sólida e forte tendência de continuidade na concepção religiosa, na concepção de mundo e na sociedade que se plasmaram ao longo de nossa história até o presente. É também bom lembrar que, durante a maior parte da história do Brasil a religião ocupou um lugar constante e privilegiado nas manifestações públicas. Sua influência vai além da constituição de ideias, normas, ritos e símbolos religiosos, mas estende-se à sedimentação, na sociedade, de formas de se comportar e de se estar junto em sociedade, emblematicamente antepostas na concepção hierárquica do catolicismo oficial versus a concepção comunitária presente na "religiosidade popular", geralmente festiva.

Dentro dessa perspectiva, é preciso considerar que a religiosidade popular não é mero artefato histórico-cultural, mas expressão de sociabilidade, pois trata-se de um reflexo da ação das pessoas e encontra-se circunscrita no cotidiano, nas faltas e conflitos das realidades de um povo. A estruturação de uma sociabilidade religiosa-violentafestiva, decorrente da marcante presença da evangelização e do monopólio religioso católico durante grande parte da história do Brasil, fez com que, por meio da efervescência cívico-religiosa das festas, se constituísse uma percepção de tempo, de espaço e de representações simbólicas específicas.

Incrustada na sociabilidade cotidiana subsiste à rememoração festivo-religiosa, uma concepção de história como um processo cíclico, mas não essencialmente estático. Trata-se, portanto, de uma recriação do passado no presente, que nutre tais manifestações de uma gama inumerável de significados e práticas distintas. Tal fato concorre para a constituição de um movimento dialético de uniformidade e diversidade. Tal processo é decorrente das múltiplas temporalidades e dos múltiplos sujeitos presentes na sociedade brasileira.

Não se pode esquecer que a implantação das práticas e das orientações religiosas no Brasil deu-se por meio da imposição de um arbitrário religioso aos povos subjugados - indígenas e africanos -, através da evangelização. A imersão moral no universo do colonizador deu-se através de um processo de violação simbólica que resultou num processo complexo de relações entre o cristianismo e os componentes religiosos- 
culturais originários dos povos colonizados e dos escravizados. Essa profunda hibridização cultural concorreu para a grande diversidade de nosso universo cultural, muitas vezes interpretada sob o símbolo do sincretismo. A popularização do termo sincretismo fez consolidar-se uma concepção dos encontros culturais em termos de uma sobreposição simbólica pretensamente harmoniosa, que estabeleceria relações de correspondência entre universos culturais distintos, concepção amplamente revista. ${ }^{1}$

No Brasil, a práxis religiosa instalou-se sobre o signo da moral violenta da evangelização. Nem sempre os encontros e diálogos entre catolicismo oficial e religiosidades populares ocorreram num nível de harmonia e de fecundidade recíproca. A violência, a tensão, os conflitos, os desencontros e as fronteiras marcaram profundamente tais fenômenos, falsamente simbolizados como harmoniosamente sincréticos. Nosso universo religioso foi composto pelo intercurso, muitas vezes conflituoso, de múltiplos sagrados.

Dessa forma, a rememoração de tais tradições é mais do que a nostalgia ancestral, sendo, também, a rememoração da violência e do jogo de negociação desde sempre em cena. A memória de tais práticas religiosas possibilita, nos presentes arranjos sociais, a legitimação de práticas e a sobrevivência de identidades e valores. Possibilita, também, um jogo de tensões simbólicas tecido em torno das diversas representações dessas manifestações correntes no imaginário da sociedade e produzidas pelos diversos atores sociais envolvidos: atores oficiais - autoridades acadêmicas, autoridades políticas, clericais dentre outros -, perspectivas produzidas por uma intelectualidade local - os folcloristas, memorialistas, simpatizantes - e até apropriações pela lógica do espetáculo.

\section{Festas e os novos olhares sobre a cultura popular}

É importante que, mais do que cultura popular, patrimônio ou monumento, as festas sejam compreendidas como formas lúdicas de sociação, principalmente no caso das relações entre sociedade e manifestações festivo-religiosas. Nesse sentido, o fenômeno da festa não é apenas mera exterioridade dessas concepções religiosas, mas estrutura suas próprias concepções de sagrado. Como afirmou Berkenbrock, "a festa nas religiões afro-brasileiras não é consequência, ela tem a ver mais com a causa"

\footnotetext{
${ }^{1}$ Sobre a revisão do conceito de sincretismo, consultar Ferreti (1995).
} 
(BERKENBROCK, 2002, p.194). Portanto, é preciso que busquemos a compreensão do lugar da festa dentro da lógica do sagrado das religiões afro-brasileiras.

Gerações e gerações de pesquisadores, que dedicaram seu regozijo intelectual ao regozijo festivo das massas, geralmente, caminharam na contramão de acepções sociais e acadêmicas que consideraram a festa, a cultura popular e até a própria cultura como realidades ou fenômenos menores. As gerações de estudiosos da cultura popular da transição para a segunda metade do século $\mathrm{XX}$ dedicaram uma maior atenção aos fenômenos pertencentes a tal universo: a herança da questão nacional, reequacionada na primeira metade do século XX a partir da semana de arte moderna de 1922 e por obras publicadas por intelectuais como Mário de Andrade, Sérgio Buarque de Holanda e Gilberto Freyre, floresceu na segunda metade do século XX concomitantemente, com a ascensão do movimento folclórico e ecumênico. Mas, apesar da importância a partir de então atribuída ao universo popular, grande parte dos estudos históricos, sociológicos e antropológicos ainda se recusava a reconhecê-lo como digno de uma maior relevância para a compreensão e para a problematização da realidade.

Muitos estudos contemporâneos discordaram dessa perspectiva e mergulharam os estudos da cultura popular numa perspectiva diferenciada da anterior obsessão pelas origens - quase metafísica. As concepções histórico-sociológicas hoje encaram tanto o passado como o presente como multidimensionais, rompendo com uma concepção linear e evolucionista que impregnava a produção científica.

A compreensão dos fenômenos do tempo passado e do tempo presente multidimensionalmente permeados por questões políticas visíveis e invisíveis, definiram um entendimento dos elos entre o tempo passado e o tempo presente como campos de possibilidades e não mais como percursos teleológicos. Dessa forma, encerram em seus fenômenos uma pluralidade de sentidos e de significados que se reproduzem e se reformulam com dinamismo, de acordo com cada contexto onde estão inseridos. A nova compreensão nada tem a ver com o anátema da descaracterização que condenava qualquer novo significado ou prática dentro da cultura popular à condição de deterioração das práticas e dos sentidos antecedentes.

Sendo assim, novas abordagens alçaram o estudo da cultura popular e das festas a um novo status como objeto de pesquisa social. Tais abordagens passaram a considerar esses fenômenos como profundamente permeados por tensões, conflitos e negociações políticas, atentando, principalmente, para as práticas e representações 
engendradas a partir da própria ação dos indivíduos e dos que as praticam. Segundo a análise de Chartier, compreender a cultura popular

\begin{abstract}
significa, então, situar neste espaço de enfrentamentos as relações que unem dois conjuntos de dispositivos: de um lado os mecanismos de dominação simbólica, cujo objetivo é tornar aceitáveis pelos próprios dominados, as representações e os modos de consumo que, precisamente qualificam (ou antes, desqualificam) sua cultura como inferior e ilegítima, e, de outro lado, das lógicas específicas em funcionamento nos usos e nos modos de apropriação do que é imposto. (CHARTIER, 1995, p.181)
\end{abstract}

A partir de então a cultura popular e as festas, compreendidas como formas de sociabilidade, passaram a significar as próprias formas de ser, estar e de se relacionar em sociedade. As festas, religiosas ou não, foram colocadas como fenômenos a serem estudados na sociedade e em relação a ela, tanto no passado como no presente. E isso significou, ao mesmo tempo, considerá-las fenômenos sociais, que estão na razão mesma de existência da sociedade e dos vínculos sociais, assim como, portadores de uma dinamicidade capaz de dotá-la do potencial de se revestir de múltiplos significados e práticas.

As festas, assim como as religiões populares, passaram a ser encaradas como fenômenos culturais permeados por dimensões políticas, econômicas e sociais estruturais, e não mais como acessórias - superestruturais. Dessa forma, parte substancial desses estudos vem, então, se dedicando às medidas de restrição ou de normalização destinadas às festas e às religiões no espaço público e no privado, ao longo da história. ${ }^{2}$ A festa e a religião, nessa perspectiva, superariam seu caráter extramundano e seriam inseridas na realidade cotidiana das sociedades, onde os conflitos políticos mais essenciais são travados e negociados. Mais do que pitoresco, esse é o lado espinhoso das festas e da fé.

\title{
Os estudos do Reinado em Divinópolis/MG: o pesquisador entre novos e velhos significados
}

Os festejos religiosos do Reinado/Congado estão altamente difundidos por todo o estado de Minas Gerais e possuem uma grande relevância cultural, religiosa e coletiva nas localidades onde ganham vida graças à ação das Irmandades de Nossa Senhora do

\footnotetext{
${ }^{2}$ Dentre esses, gostaria de destacar os trabalhos de Martha Abreu, Maria Clementina Pereira Cunha e Patrícia Vargas Lopes de Araújo, Patrícia de Araújo Brandão Couto.
} 
Rosário, São Benedito, Nossa Senhora das Mercês, Santa Ifigênia, Nossa Senhora Aparecida etc. As coroações de reis negros, os Congos, as Congadas e os Reinados estão presentes no Brasil desde o período colonial, em um sem número de formas e de significados próprios, engendrados diante de contextos históricos específicos em cada momento e localidade.

Formas de religião místico-performático-musical-teatrais como o Reinado possibilitam o exercício de uma memória afetiva familiar-ancestral, que é construtora de identidades. No caso desses festejos, a identidade afro-católica continua a se sedimentar, pois, através da evocação cíclica e festiva, a memória permanece viva. O risco de esvaecimento de tais práticas pode gerar a distância e o desconhecimento, a não lembrança, a restrição à memória, e a transformação profunda do processo de constituição de identidades, a constituição de novas formas de rememoração.

À medida que a religião, assim como tantos outros aspectos da vida social, vai se tornando cada vez mais um assunto da esfera do privado e objeto de escolha dos indivíduos, mudanças correspondentes vão ocorrendo no campo da concepção do sagrado, do espaço e do tempo. O exercício coletivo da memória necessita da continuidade de práticas que sirvam de suporte para a manutenção de tais manifestações. A existência de práticas como as do Reinado/Congado, assim como outras práticas religiosas populares, garante, em certa medida, a reevocação de uma memória social da coletividade, constantemente reconstruída e colocada diante de vetores sociais que pendem para um individualismo muitas vezes predatório. A prevalência da festividade e da afetividade como fator estrutural nessas manifestações religiosas pode nos permitir a compreensão da recriação, em plena sociedade da mudança, de uma sociabilidade da permanência do coletivo, decorrente da constante recriação do estar-junto em sociedade.

$\mathrm{O}$ contexto herdado da primeira metade do século $\mathrm{XX}$ fez com que o campo religioso brasileiro fosse definido sob a sombra das relações entre Igreja Católica e Estado, mesmo depois de rompidas e profundamente abaladas as relações entre tais instituições, após o estabelecimento da república. Tal fato contribuiu para que, mesmo que gerido por constituições laicas e teoricamente garantidoras do estado laico, o espaço público e o campo religioso brasileiro se definissem em função do jogo de interesses entre catolicismo e poder republicano.

Porém, as mudanças ocorridas no campo intelectual e político brasileiro, nas estruturas internas da Igreja Católica, assim como no próprio campo religioso 
brasileiros fariam com que a ocorrência de profundas transformações pudessem ser percebidas ao longo da segunda metade do século $\mathrm{XX}$, alterando consideravelmente o lugar hegemônico do catolicismo. Tal fenômeno, associado ainda a outras variáveis, fez do Brasil contemporâneo um campo completamente novo de possibilidades de existência e de significação para práticas como aquelas dos festejos afro-católicos do Reinado, e abriu novas perspectivas de usos e de apropriações do espaço público das cidades, pelas práticas de festas/cultos religiosos.

Em outro trabalho, tratei das tensões em torno da realização de tais festas nas perspectivas diacrônica e sincrônica (LEONEL, 2009). Historicamente, foi possível confirmar através de documentação arquivística e de entrevistas de história oral temática, as determinações do Arcebispo de Belo Horizonte D. Cabral, a partir da década de 1920, de coibir a realização de festejos religiosos afro-brasileiros.

Foram largamente registradas, na produção memorialista e folclorista dos homens de letras em Divinópolis, as proibições do arcebispo de Belo Horizonte dos festejos e das práticas religiosas em meio à sociedade, por volta da década de 1920. Através das fontes compostas por correspondências, circulares, determinações e, sobretudo, a imprensa católica, foi possível entender como a Arquidiocese de Belo Horizonte propagava um discurso combativo aos inúmeros cultos não-católicos, dentre os quais se destacam as práticas da religiosidade demasiadamente festiva, geralmente identificadas com as populares.

A referência depreciativa a essas práticas se fazia pela crítica a múltiplos aspectos, representativos da multiplicidade de tais formas: as externalidades da dança, da música e do espetáculo; a comilança, bebedeira e jogatina decorrentes das práticas das barraquinhas; o curandeirismo místico-religioso; o contato com o mundo dos espíritos ou do ocultismo, representados em centros espíritas, reuniões como, também, nos terreiros; a interseção com significados religiosos do próprio catolicismo ibérico, por meio da demasiada intimidade com santos, como nos cortejos, procissões, reinados e batalhas. Pode-se dizer que as práticas do Reinado incluíam-se, sobretudo, na última característica elencada, mas poderia, dependendo do contexto, trazer um pouco de todas elas, ou algumas dessas práticas e dessas significações, assim como outras não listadas aqui.

O Município de Divinópolis era ponto chave da arquidiocese tanto por ajudar a capitanear o catolicismo institucional nos moldes da década de 1920, representado pela instalação do seminário dos franciscanos holandeses, como por centralizar, já nessa 
época, os Reinados da região centro-oeste mineira. Em 1932, um processo instaurado na Secretaria do Interior do Estado de Minas Gerais, a partir do pedido feito ao delegado por D. Cabral por meio de bilhete ali anexado, lista, começando por Divinópolis, "os municípios em que ainda as autoridades têm permitido o tal reinado.”3

Através da análise do discurso do bilhete do arcebispo, é possível notar dois elementos fundamentais: as práticas do Reinado persistiam, a despeito das proibições, e mais, contavam com a tolerância das autoridades não só das policiais, mas também de algumas autoridades religiosas.

O debate iniciado por esse documento permite observar as táticas e estratégias adotadas pelas autoridades no sentido de coibir, controlar ou até permitir os festejos e, em contrapartida, as trilhas abertas, conquistadas ou batalhadas pelos festeiros de modo a persistir com suas práticas religiosas. Assim, os pareceres do processo da Secretaria de Interior eram indicativos de que a regulação do espaço público da festa religiosa era permeada por fatores complexos como a tradicionalidade dos festejos, o apadrinhamento de famílias respeitáveis e tradicionais dos lugares, incluindo aí a falta de respaldo na lei, citada pelo delegado, para proibir, pois cabia antes às autoridades policiais o controle das ações populares.

Percebem-se, aí, as estratégias das autoridades, não de coerção, mas, também, de normatização, controle e, até, tolerância. Tal perspectiva não significou o esvaziamento das lutas empreendidas pelos festeiros no sentido de prosseguir com sua fé, mas uma complexificação das táticas empreendidas nesse sentido, que contou com a cooptação, inclusive dos meios destinados ao seu próprio controle.

As três décadas seguintes às de 1920/30, mostraram, também, anos de desencorajamento velado a tais práticas. O discurso da miscigenação brasileira, empreendido como representação da identidade nacional, foi concomitante à coerção e ao controle de algumas práticas religiosas, principalmente aquelas de maior acento afro fossem as práticas mais ligadas ao imaginário católico, como a dos Reinados, como aquelas mais próximas ao imaginário dos terreiros, em diferentes proporções. Ao mesmo tempo, tais manifestações eram resignificadas a partir da nova identidade nacional, enunciada por parte da intelectualidade brasileira pós-1922 nas letras, nas artes, na sociologia, história etc.

\footnotetext{
${ }^{3}$ PARECER da Secretaria do Interior de Minas Gerais Sobre o pedido do Arcebispo Dom Cabral De proibição às festas Do Reinado. Arquivo Público Mineiro. Operaç̃̃es policiais, Belo Horizonte, 1932.
} 
Além das proibições de D. Cabral, quatro marcos históricos foram fundamentais para a compreensão das continuidades e rupturas que permearam a história dos Reinados em Divinópolis ao longo do século XX: a) 1957: a demolição da igreja e do cemitério do Rosário, em fins do século XIX, desalojando a irmandade homônima, principal responsável pela realização dos Reinados; b) 1977: a realização da primeira Missa Conga no município, selando a reconciliação entre Igreja Católica e Reinado e a criação de novas formas de sobrevivência da festa, validadas institucionalmente; c) 1984: a construção da capela monumento no local da antiga Igreja e cemitério do Rosário, redemarcando, com o apoio do poder público e religioso, o espaço urbano ancestral de realização dos festejos; d) 2005: a restituição do terreno da capela monumento à Irmandade do Rosário e de São Benedito na Praça do Mercado, em cerimônia política que contou com a presença do então ministro da cultura, Gilberto Gil.

Tal sequência linear de datas representa mudanças significativas nas relações dessa sociedade com as práticas e os significados das festas do Reinado, no decorrer da segunda metade do século XX. A demolição da Igreja do centro da cidade gerou a fragmentação da irmandade original ao meio, que se subdividiu em duas novas irmandades instaladas em bairros mais distantes do centro. ${ }^{4}$ A partir daí, até o presente, as irmandades e guardas/ternos ${ }^{5}$ pulverizaram-se pelos bairros e bordas da cidade, chegando hoje a quase duas dezenas. ${ }^{6}$ A partir de 1977, com a criação da Missa Conga, a festa passou a ser resignificada diante de uma nova relação com o catolicismo e com o apoio dos movimentos folclóricos. Além da cooptação dentro das orlas da Igreja Católica, o poder municipal também passou a apoiar e a regular a existência dos festejos, incorporando-os na agenda de ações políticas culturais anuais, o que garantiu seu retorno oficial ao centro da cidade, não só com as Missas Congas, mas, também, com a construção da capela monumento.

\footnotetext{
${ }^{4}$ Porto Velho e Niterói.

${ }^{5}$ Os Ternos, Cortes ou Guardas (termos sinônimos da região) são os grupos diferenciados envolvidos na organização e realização dos festejos: são os responsáveis pela proteção dos festeiros, Reis e Rainhas, e pela dimensão musical das festas. Cada guarda desempenha uma função específica na lógica da festa e possui um universo musical próprio (marcado pelos graves toques de tambores), entoando cantos de louvor onde prevalecem determinados padrões rítmicos, assim como o uso de instrumentos musicais e vestes específicas. Na região encontram-se uma grande variedade delas: Guarda de Vilão, Guarda de Catopé, Guarda de Penacho, guarda de Marinheiro, além das guardas de Congo e Moçambique, que desempenham funções imprescindíveis para o funcionamento do Reinaldo e por isso trata-se de um denominador comum da festa em todo Estado de Minas Gerais.

${ }^{6}$ Os números mais atuais da Secretaria Municipal de Cultura de Divinópolis (SEMC) indicavam cerca de 17.
} 
Tais mudanças colocam os Reinados num novo posicionamento no campo de poder local, de forma que tais festejos passam a ser apropriados como símbolo políticoreligioso da identidade local. Tal fato insere o Reinado em meio a um novo campo de tensões, marcado, dentre outros por seu trânsito em meio ao catolicismo institucional, por sua condição de alvo das políticas culturais e por constituir-se representação midiática de uma identidade local.

Obviamente, ao longo do século XX até a total relegitimação do Reinado na sociedade divinopolitana, alternaram-se períodos de maior ou de menor tolerância. A revelia das regras, por afronte ou desconhecimento delas, além dos circuitos legais, as estratégias dos festeiros também correram pelas margens: evitando o centro da cidade, ocorrendo pelas bordas; contando com a simpatia de alguns vizinhos; parando seus tambores ao passar pelas igrejas ou pelo centro; burlando as autoridades ou, simplesmente, exigindo seus direitos legais de culto e de trânsito no espaço público.

Subjacentemente aos velhos e novos conteúdos, para os reinadeiros, mais do que uma herança étnica, os Reinados celebraram e celebram o estar-junto, custe o que custar. Para isso, cria há tempos formas de sociabilidade e solidariedade que reúnem indivíduos pela fé, pela festa, por laços de vizinhança, parentesco, assistência etc. A própria prática de troca de guardas entre diferentes municípios e distritos cria uma teia de relações que transcende os limites municipais e propõe uma vasta teia de sociabilidade, solidariedade e celebração, garantindo a continuidade em meio às diversas rupturas apuradas.

Dessa forma as festas não levitam sobre a sociedade, elas ocorrem no tempo e no espaço, permitindo que a dimensão sagrada atribuída a elas permeie ambas as dimensões. Em Divinópolis, como nas cidades do centro-oeste mineiro, por exemplo, as práticas do Reinado, paralelamente às outras dinâmicas urbanas que vão se desenhando, ainda dão ritmo e formato ao tempo dos lugares, assim como promovem usos e apropriações diversas do espaço público urbano. Por isso mesmo, a incursão pelo sagrado nesse universo festivo é composta por uma intensa multiplicidade de práticas e de sentidos. Mesmo que todas essas manifestações compartilhem sinais festivos comuns, as variações são inumeráveis e as combinações são infindas e inesperadas, pois correspondem a demandas, a necessidades e a anseios muito específicos.

Nos Reinados, em todo o extenso calendário de atividades que preparam a culminância dos festejos, pode-se perceber o intenso engajamento religioso e social dos grupos. Verifica-se aí aquilo que, nas palavras de Certeau, seria chamado de uma 
"consciência de vida", mesmo que diversificada e disseminada (CERTEAU apud PASSOS, 2002, p.181). As festas em favor de Nossa Senhora do Rosário ocorrem com danças, cantos, música, procissões, almoços, cafés, levantamentos de mastros, translados de coroas e festeiros, ou seja, com muita movimentação e agitação. Promovem nos inúmeros percursos e trajetos feitos e percorridos pelas guardas, uma verdadeira celebração da cidade como espaço sagrado da convivência. Religião, magia e mística misturam-se numa religiosidade altamente cotidiana, humanizadora do sagrado e geradora de uma rememoração identitária muitas vezes transformadora, capaz de moldar percursos e trajetos de vida.

A despeito do que se pensa no senso comum, expressões religiosas como os Reinados e os Congados, antes considerados como arcaísmos ou resquícios da religiosidade colonial, podem hoje mostrar uma substancial vitalidade. Isso pode ocorrer justamente por se apresentarem como alternativas de convivência em coletividade, de redes de solidariedade e de possibilidade de rememoração ativa de tradições afetivas pessoais, familiares e coletivas que estabelecem pertencimentos a grupos, identidades e lugares. Além disso, a flexibilidade e o convívio com a multiplicidade, inerentes às estruturas de tais manifestações religiosas, permitem o pertencimento múltiplo ou transversal a diversas crenças religiosas, o que é profundamente consoante com o novo habitus religioso que vem se estabelecendo nas sociedades contemporâneas.

Manifestações festivo-religiosas como o Reinado, mesmo que sob o discurso da constante ameaça do perecimento das culturas populares, possuem um alto potencial de reestruturação e resignificação diante de desafios e de novas conjunturas contemporâneas, concomitante ao esforço para se manterem fiéis às tradições católicas, afro-católicas, familiares etc. Talvez por isso tenham mostrado tamanho crescimento em Divinópolis ao longo das últimas quatro décadas, a despeito de um histórico marcado pela aversão institucional da Igreja Católica, proibições eclesiásticas e intervenções policiais para o seu controle/repressão na $1^{\mathrm{a}}$ metade do século XX.

A busca, hoje, do pertencimento a manifestações religioso-festivas como o Reinado, notadamente expressões coletivas de fé, pode também ser interpretada como busca individual pela transcendência ou pela espiritualidade, por meio dos elementos mágico-afetivo-sensitivos presentes em tais cultos/festejos e consoantes aos atributos da mística: a dimensão festiva do Reinado permite, também, o contato direto com o universo do sagrado sem a obrigação de intermediações hierárquicas ou ritos 
inflexivelmente estruturados, em grande parte, através de recursos rituais permeados pela música, pela dança ou pela teatralidade. São formas de agradar tanto aos sentidos quanto a Deus e aos santos. Além disso, a relação com o universo do sagrado dá-se tanto individualmente como coletivamente, no prazer transcendente do contato consigo e com o outro no encontro festivo.

Dessa forma, pode-se dizer que, hoje, manifestações religioso-festivas como o Reinado ganham um novo sentido de existência, diante das profundas mudanças ocorridas no campo religioso brasileiro, pois, em sua dinamicidade, reúnem aspectos da comunidade, da igreja e da mística (STEIL, 2003), permitindo o multipertencimento da religiosidade transversal contemporânea, seja ele concomitante ao catolicismo, ao kardecismo ou aos terreiros. Além disso, a pertença a tais manifestações e a notoriedade pública proporcionada por ela constitui, também, capital cultural individual e coletivo, que possibilita (auto) afirmação identitária e pertencimento a um grupo, mesmo que flexível, além da atribuição a tais manifestações do status de patrimônio cultural.

\section{Considerações Finais}

Apesar de importante, o alcance da popularidade do conceito de cultura e religiosidade popular apresenta problemas analíticos sérios para os pesquisadores mais desavisados. O avanço da Igreja Católica, pós-Concílio Vaticano II, e da sociedade civil em termos de ecumenismo teve efeitos importantes, mas apresentou, no balanço contemporâneo, resultados também limitados. O atual contexto, apesar de todas as conquistas decorrentes da redemocratização político-social e do campo religioso brasileiro, não é dos mais progressistas. Enquanto a Igreja Católica vem, ao longo das últimas duas décadas, mostrando certa retração, se não em relação ao diálogo ecumênico, em relação à opção preferencial pelos pobres, a perseguição simbólica das religiosidades de acento afro, dantes encabeçada pelo próprio catolicismo, foi apropriada por uma série de vertentes neo-pentecostais que promovem, nos seus cultos e no espaço público da mídia de massa, com concessões de sinais públicos, uma sistemática perseguição e desqualificação do universo religioso afro-brasileiro, mais especificamente das práticas provenientes dos terreiros de umbanda e de candomblé.

Simbolicamente embrulhadas no status de patrimônio cultural local ou respaldadas por figurarem, hoje, como genuínas manifestações do catolicismo popular, mesmo as festas do Reinado não escapam ilesas aos novos conflitos. O panorama de 
realização das festas do Reinado em Divinópolis/MG apresentou um vertiginoso crescimento ao longo das últimas três décadas. Mesmo não figurando, nem de longe, entre os alvos preferidos das ofensivas neo-pentecostais, tais manifestações permanecem inseridas em um campo de forças onde sua existência, qualificação ou desqualificação estão permanentemente em jogo. Relações com a instituição católica, relações com políticas públicas de apoio à cultura popular, apadrinhamento por figuras políticas, subvenção para construção das igrejas das irmandades responsáveis pela festa etc., articulam a construção de novos significados em torno dessas festas. ${ }^{7}$

Para além da existência de tais conflitos e tensões, é importante, por fim, salientar o que a existência de tais festejos religiosos é apenas a manifestação mais facilmente notável, por seu caráter festivo e público, de redes de relações sociais e de solidariedade criadas por laços de vizinhança, parentesco, comunhão religiosa, regozijo coletivo-festivo etc. Através da atuação coletiva, das irmandades, das guardas, dos festeiros, dos pagadores de promessas, de simpatizantes, ano após ano, quase que ininterruptamente ao longo de décadas e décadas, os Reinados e Congados são festejados. A atuação coletiva integrada de tais atores sociais na organização e performance da festa significou e significa, muitas vezes, a possibilidade de protagonismo social e de utilização do espaço público confiscado, seja ao longo da história ou mesmo do ano vigente.

\begin{abstract}
The festivals and "popular" religiosities have been for a long time approached themes in the folklorists' research, memorial writings and also academic researches. However, not always such phenomena were/are properly faced and studied considering its real relevance and social complexity, either in the past or in the present. The objective of this article is to list different approaches and propose research perspectives related to the social studies of traditional festivals, religiosities and other "popular" manifestations, throwing new light on such phenomena. This way, it is possible to promote new ways of facing such themes through interdisciplinar analysis that can result in different approaches of these phenomena in its continuities and singularities.
\end{abstract}

Key words: Festivals; Sociability; Popular culture.

\footnotetext{
${ }^{7}$ Questões também tratadas mais detidamente no meu trabalho de dissertação, já referenciado.
} 


\section{Referências}

ABREU, Martha. O Império do Divino: festas religiosas e cultura popular no Rio de Janeiro, 1830-1900. Rio de Janeiro: Nova fornteira; São Paulo: Fapesp, 1999. 406p.

ALMEIDA, Ronaldo R.M. de; MONTERO, Paula. O Campo religioso brasileiro no limiar do século: problemas e perspectivas. In: RATTNER, Henrique (org.). Brasil no Limiar do Século XXI. São Paulo: Editora da Universidade de São Paulo, 2000. p.325340 .

ARAÚJO, Patrícia Vargas Lopes de. Folganças populares: festejos de entrudo e carnaval em Minas Gerais no século XIX. São Paulo: Annablume, 2008. 183p.

BERKENBROCK, Volney J. A festa nas religiões. In: PASSOS, Mauro. A festa na vida: significado e imagens. Petrópolis: Vozes, 2002. p.191-223.

CANCLINI, Nestor Garcia. As culturas populares no capitalismo. São Paulo: Brasiliense, 1983. 149p.

CANCLINI, Nestor Garcia. Culturas híbridas: estratégias para entrar e sair da modernidade. 3. ed. São Paulo: Editora da Universidade de São Paulo, 2000. 416p.

CERTEAU, Michel de. A invenção do cotidiano: artes de fazer. Petrópolis: Vozes, 1994. 352p.

CHARTIER, Roger. "Cultura popular: revisitando um conceito historiográfico". Estudos Históricos, Rio de Janeiro, v. 8, n. 16, p.179-192, 1995.

COUTO, Patrícia de Araújo Brandão. Festa do Rosário: iconografia e poética de um rito. 2001. 188 f. Dissertação (Mestrado em Antropologia) - Universidade Federal Fluminense, ICHF.

CUNHA, Maria Clementina Pereira. Ecos da folia: uma história social do carnaval carioca entre 1880 e 1920. São Paulo: Companhia das Letras, 2001. 395p.

DURKHEIM, Émile. As formas elementares da vida religiosa. 2. ed. São Paulo: Paulus, 1989. 535p.

FERRETI, Sergio Figueiredo. Repensando o sincretismo: um estudo sobre a Casa das Minas. São Paulo: Editora da Universidade de São Paulo, 1995. 234 p.

HOBSBAWN, Eric. A invenção das tradições. Rio de Janeiro: Paz e terra, 1984. 316p.

LARA, Silvia Hunold. Significados cruzados: um reinado de congos na Bahia setecentista. In: LARA, Silvia Hunold. Carnavais e outra $f(r)$ estas. Campinas, São Paulo: Editora da Unicamp, 2002. p.71-100.

LEONEL, Guilherme Guimarães. Entre a cruz e os tambores: conflitos e tensões nas Festas do Reinado (Divinópolis - MG). 2009. 247 f. Dissertação (Mestrado em Ciências Sociais) - Pontifícia Universidade Católica de Minas Gerais. 
LEONEL, Guilherme Guimarães. "Estratégias de resistência e perspectivas de controle, coerção e tolerância às festas do Reinado em Divinópolis- MG". Revista Brasileira de História das Religiões, Ano 1, n. 2, p.207-245, 2008. Disponível em: http://www.dhi.uem.br/gtreligiao/n2-2008.html.

MAGNANI, José Guilherme Cantor. Festa no pedaço: cultura popular e lazer na cidade. São Paulo Brasiliense, 1984. 198p.

MAGNANI, José Guilherme Cantor. "De perto e de dentro: notas para uma etnografia urbana". Revista Brasileira de Ciências Sociais, São Paulo, v. 17, n. 49, p.11-29, jun. 2002.

MAGNANI, José Guilherme Cantor. "Da periferia ao centro: pedaços e trajetos". Revista de Antropologia. São Paulo, v. 35, p.191-203, 1992.

MONTERO, Paula. Religiões e dilemas da sociedade brasileira. In: MICELI, Sergio (org.). O que ler na ciência social brasileira (1970-1995). São Paulo: Sumaré, 1999. p.327-366.

PASSOS, Mauro (org.). A festa na vida: significado e imagens. Petrópolis: Vozes, 2002. 224p.

PEREZ, Lea Freitas. "Dois olhares sobre o urbano: Max Weber e Escola de Chicago". Veritas, Porto Alegre, v. 39, n. 156, p.621-637, dez. 1994.

PEREZ, Lea Freitas. "A cidade e a modernidade: Equívocos conceituais". Biblos, Rio Grande, v.10, p.109-116, 1998.

PEREZ, Léa Freitas. Antropologia das efervescências coletivas. In: PASSOS, Mauro. A festa na vida: significado e imagens. Petrópolis: Vozes, 2002. p.15-58.

PEREZ, Léa Freitas; QUEIROZ, Rubem Caixeta de; VARGAS, Eduardo Viana (org.) "Passagem de milênio e pluralismo religioso na sociedade brasileira". Teoria \& Sociedade, Belo Horizonte, Número Especial: Passagem de Milênio e Pluralismo Religiosos na Sociedade Brasileira, 2003.181p.

REIS, João José. Tambores e temores: a festa negra na Bahia na primeira metade do século XIX. In: CUNHA, Maria Clementina Pereira (org.). Carnavais e outra f(r)estas. São Paulo: Editora da Unicamp, 2002. p.101-155.

SAHLINS, Marshall. Ilhas de história. Rio de Janeiro: Jorge Zahar, 1990. 218p.

SANCHIS, Pierre. "A religião dos brasileiros". Teoria \& Sociedade, Belo Horizonte, Número Especial: Passagem de Milênio e Pluralismo Religiosos na Sociedade Brasileira, p.16-49, 2003.

SCHWARCZ, Lilia K. Moritz. "Complexo de Zé Carioca: notas sobre uma identidade mestiça e malandra". Revista Brasileira de Ciências Sociais, Ano 10, n. 29, p.43-63, out. 1995. 
SIMMEL, Georg. A metrópole e a vida mental. In: SIMMEL, Georg. O fenômeno urbano. Rio de Janeiro: Zahar, 1987. p.10-25.

SIMMEL, Georg. El problema religioso. Buenos Aires: Prometeo Libros, 2005. 91p.

SIMMEL, Georg. Questões fundamentais de sociologia. Rio de Janeiro: Zahar, 2006. $119 \mathrm{p}$.

SOARES, Carlos Eugênio Líbano. Festa e violência: os capoeiras e as festas populares na corte do Rio de Janeiro (1809-1890). In: CUNHA, Maria Clementina Pereira (org.). Carnavais e outra f(r)estas. Campinas: Editora da Unicamp, 2002. p.281-310.

STEIL,Carlos Alberto. "Da comunidade à mística". Teoria \& Sociedade, Belo Horizonte, Número Especial: Passagem de Milênio e Pluralismo Religiosos na Sociedade Brasileira, p.144-155, 2003.

VELHO, Gilberto. Observando o familiar. In: NUNES, Edson de Oliveira (org.) A aventura sociológica: objetividade, paixão, improviso e método na pesquisa social. Rio de Janeiro: Zahar, 1978. p.37-46

VILHENA, Luís Rodolfo. Projeto e missão: o movimento folclórico brasileiro (19471964). Rio de Janeiro: Funarte, 1997. 331p.

WEBER, Max. A ética protestante e o espírito do capitalismo. São Paulo: Martin Claret, 2007. 238p. 